3-A4-161* 発熱、高サイトカイン血症を示す免疫病 例の検討：平林泰彦 1 、無量井泰 1 、柴田忍 1 、渡遑美紀 1 、 高橋裕一2、石井智徳? 船渡忠男 2 、佐々 木毅1 ( ${ }^{1}$ 東北 大·免疫血液病制御、2 同 - 分子診断学)

（目的）SLEを始めとする自己免疫疾患では、持続す る発等を示す例が少なくない。この場合基礎疾患の 活動性との関連が問題とされるが、しばしば合併症 との鑑別も困難である。この様な病態の解析を試み た。

（方法及び成績）1、主としてSLEを中心とした発熱 が一回以上出現する免疫疾患病態について、各検查 所見、特に炎症性サイトカインの動態、凝固線溶系、 骨噵、ウィル、学的所見を追求した。2、熟熱出 おいて、血中IL-6、INF- $\alpha$ 、IFN- $\gamma$ 、可溶性IL-2レセブ 夕一値の上昇、汎血球减少症、LDH値高値を認めた。 6 例中 4 例では血球全食症候群とされ、また 5 例に おいてサイトメガロ(CMV)、EB(EBV)あるいはヒトパ ルボウィルスB19(B19)DNAが検出された。

(結論及び考察) 持続する高熱を主体とし、高サイ トカイン血症が出現する例ではしばしば血球領食症 候群を合併する。この病態の原因としてCMV、EBV、 要とされる。 没し、多彩な自己抗体が陽性の 6 例（5例はSLE）に B19が関与しうるので、特にウィルスのDNA診断が必

3-A4-163* 肺炎球菌による急性喉頭蓋炎、肺炎に併発 した血球領食症候群の一女児例

〜血清サイトカインの検討〜

北里大学医学部小児科

石川義人、野間 剛、教島康史

佐伯敏亮、川野 豊、松浦信夫

はじめに: ウイルス関連血球貪食症候群 (VAHS) は、骨 膸の血球荟食 (HP) を主徵とし、T細胞を含む種々の細胞か ら分泌される炎症性サイトカインによる組織障害を示す高サ イトカイン疾患であり、EBウイルスなどにより誘導される場 合が多い。細菌感染に関連する血球領食症候群 (BAHS) の 報告もみられるが、その病因、病熊の解明は十分ではない。 肺炎球菌による喉頭蓋炎、肺炎に伴い沉血球減少とHPを示 した一症例を経験したので報告する。症例 : 生来健康な5歳 女览。呼吸困難、発熱を主訴に来院した。急性喉頭蓋炎と診 断され入院したが、白血球は600/ $\mu$ 1と低下を認め、血小板 と血色素は $0.5 \times 10^{4} / \mu 1 、 6.0 \mathrm{~g} / \mathrm{dl}$ まで減少した。骨髄所見 は、低形成（有核細胞数 $13000 / \mu 1$ 、巨核球 $46 / \mu 1$ ) を認め、 艏索内ではfoamyな胞体を有する組織球系細胞が相対的に增 加し、正常細胞の食食像を認めた。血清フェリチンは、

8844ng/mlまで上昇した。扁桃および血液培美から肺炎球菌 を同定し、肺炎球菌感染症に併発したBAHSと診断した。血 清中のM-CSFは3935U $/ \mathrm{ml}$ (正常 $<1000 \mathrm{U} / \mathrm{ml}$ ) と高値を示 した。VP-16、メチルプレドニンパルス療法、顆粒球輸血な どにより加療し、血小板の軽度の増加を認めたが、臨床的な 改善はなかった。肺炎から呼吸不全を併発し、DICの增要を 認め、入院31病日に死亡した。考察 : 本症は肺炎球菌感染症 により誘導された高サイトカイン血症が端緒となり、HPお よび他臓器の組織障害が誘導された可能性が推測された。他 のサイトカインの血清値も合わせて検討し報告する。

\section{3-A4-164* 全身性強皮症における血清中CTGF濃度の測定：}

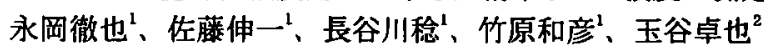
( ${ }^{1}$ 金沢大・医・皮席科、 ${ }^{2} \mathrm{JT} \cdot$ 医薬探索研)

井上佳也, 加藤政彦, 茂木洋一, 徳山研一, 森川昭廣 （群馬大·医・小児）

（目的）Granulocyte colony-stimulating factor (以下GCSF) は、好中球前駆細胞の分化促進や、成熟好中球数の 增加及び機能六進作用を持つことが知られている。一方、 川崎病患児の未梢血液像においては好中球数增加や核左方 移動を認める。今回、我々は川崎病患児の血清中G-CSFを 測定した。さらに、活性酸素による内皮細胞障害によって 産生される過酸化脂質を検討した。

（方法）対象は川崎病患児16例（男児9例女児7例、2.9土 0.8 歳)。冠動脈瘦合併は2例。急性期 $(4.6 \pm 1.3$ 病日) 之 回復期（20.7 \pm 5.3 病日）の血清を用い，ELISA法により G-CSFを、八木別法により過酸化脂質を測定した。

(結果) 急性期、G-CSFは全例で検出（138.5 \pm 52.3 $\mathrm{pg} / \mathrm{ml})$ されたが、回復期には減少し、17例中15例が測定 感度以下 $(<39 \mathrm{pg} / \mathrm{ml})$ であった。過酸化脂質は、急性期 に有意に高值 $(86.7 \pm 22.1$ vs $37.5 \pm 9.7 \mathrm{nmol} / \mathrm{ml}$, $\mathrm{p}<0.05)$ で、G-CSFに比較し、回復期に向けて緩徐に低 下する傾向を認めた。G-CSF、過酸化脂質、好中球数、 CRP各々において相関関係は認められなかった。 （結語）川崎病の病態は不明である。今回の検討により、 急珄期の病態にG-CSFや活性酸素による内皮細胞障害が関 与している可能性が示晙された。
[背景] Connective tissue growth factor (CTGF) は transforming growth factor- $\beta$ (TGF- $\beta$ ) により刺激され た線維芽細胞より産生され、線維芽細胞の增殖、コラーゲン合 成を促准させることが知られている。我々は以前に全身性強皮 症 (systemic sclerosis; SSc) の皮磨硬化部位におけるCTGF mRNAの発現增強をみいだし、CTGFがSScの病態形成に深く 関与している可能性を指摘した。[目的] SSc患者血清中の CTGFの濃度を測定し、臨床的、血清学的特幑之の相関につい て検討する。[方法］我々は抗CTGFモノクローナル抗体を作 成し、CTGFに対するELISA法を確立した。このELISA法を用 いて、SSc患者60例、揵常人30例における血清中のCTGF濃度 を測定した。[結果] SSc患者血清中のCTGF穠度は煡常人に 比べ有意に高値であった。さらにdiffuse cutaneous SSc患者 におけるCTGF濃度はlimited cutaneous SSC患者に比べ有意 に高値を示した。抗核抗体別では抗topoisomerase I 抗体陽性 群、抗U1RNP抗体陽性群におけるCTGF濃度は抗centromere 抗体陽性群に比べ有意に高値を示した。各種臨床、検查所見と の相関については、CTGF高値群では肺線維症、\%VCの低 下、\%DLcoの低下、指尖宿凹性痵痕、舌小帯短緢、全身のび まん性色素沈着、毛細血管拡張がCTGF正常群に比へ有意に多 く認められた。[結論]CTGF数度はSSC患者血清中で上昇し ており、さらにSSCの重症度との相関が認められたことより、 CTGFがSScの病態形成に関与していることが示唆された。 
3-A5-165 の機能低下：改正恒庭 筒井ひろ子 ${ }^{3}$ 、田中貴志 ${ }^{4,5}$ 、竹田 潔 ${ }^{2.5}$ 、中西䩛司 ${ }^{3}$ 、審良静男 ${ }^{2.5}$ (兵庫医大 . ${ }^{1}$ 先医研、 ${ }^{3}$ 免疫、 ${ }^{5}$ 生化、 ${ }^{2}$ 科技団·CREST、 ${ }^{4}$ ハーバード大学)

【目的】転写因子 Ig/EBP-1 は、当初、IgH エンハンサーと結 合する、C/EBP ファミリーに属するタンパクとして同定され た。しかし、B 細胞ばかりでなく、T細胞など種々の組織で 広範囲に発現が認められ、生体内における機能的意義につい ては全く不明であった。今回、我々は、Ig/EBP-1 欠損マウス を作成することにより、NK 細胞の機能に Ig/EBP-1 が必須で あることを示唆する知見を得たので報告する。

【方法および結果】 Ig/EBP-1 ホモ変異マウスは生後 24-48 時 間で死亡した（原因は現時点では不明）。そこで、血球系に おける Ig/EBP-1 の機能を解析するため、ホモ変異マウス、正 常マウスそれぞれの新生仔脾臓細胞を X 線照射 C57BL/6 マ ウスに移入し、キメラマウスを作成した。ホモ変異マウス脾 臓を移入したマウスにおいては、T,B 細胞の 分化過程に特に 異常は認められなかった。また、B 細胞の LPS に対する増殖 反応も、比4によるクラススイッチもほほ正常であった。一 方、脾臓、肝臓における NK 細胞の数は、約 50\%に低下して おり、脾細胞の YAC-1 に対する細胞障害活性も、20\%以下に 低下していた。さらに、正-12/L-18による脾細胞の IFN $\gamma$ 産 生誘導能は、正常の約 30 分の 1 以下と著明な低下が認められ た。

【結論】転写因子 Ig/EBP-1 は、NK 細胞の活性化に必須の役 割を果たしていると考えられる。現在、そのメカニズムに関 して、さらに解析中である。

3-A5-166 NKß細胞はin vitroでV $\alpha 14 N K T$ 細胞に分化する: 佐藤 宏、田中 裕二郎、中山 俊憲、谷口 克（千葉大 院・免疫発生)

（目的）新しいリンパ球サブセットであるV $214 N K T$ 細胞は

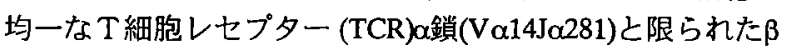
鎖（主にVB8）を発現している。これらのTCRのV $\alpha 14 \mathrm{NKT}$ 細 胞の分化における役割について解析するなかで、RAG-1/

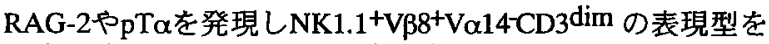
示す細胞を同定し、以前の本学会においてNKT細胞の前駆細 胞のひとつの候補として報告した。今回この細胞（NK $\beta$ 細胞 と呼ぶ)を用いて、実際にV $\alpha 14 \mathrm{NKT}$ 細胞に分化しうるか否か を検討した。

(方法) VB8トランスジェニックマウス( $\mathrm{Tg})$ を用い、 NK $\beta$ 細胞をFACSにより分画し、各種条件下で培養後 の表現型の変化をFACSにより比較した。さらにPCR 法によりTCR遺伝子再構成について検討した。

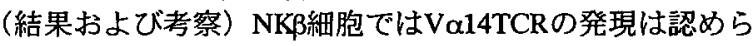
れないが、IL-15などのサイトカイン存在下に骨髄ストロー マ細胞之共培盖後、V $\alpha 14 \mathrm{~J} \alpha 281$ 遺伝子再構成が認められるよ うになりNK1.1+CD3+の表現型を示す細胞に分化した。この ときVa14-J $\alpha 281$ 遺伝子再構成に伴って形成される環状DNA が検出されることから in vitroでTCR $\alpha$ 鎖遺伝子の再構成が起 こっていることが示唆された。 $\beta 2$-microglobulinノックアウト マウス由来のストローマ細胞を用いた場合分化は認められな いことから、CD1を発現した細胞の存在が、分化に必要なこ とが示唆された。またV $\beta 8 \mathrm{Tg}$ マウスではNK緗胞が消失して 全てがNK1.1+V $\beta 8+$ 細胞へ分化していることから、V $\alpha 14 \mathrm{NKT}$ 細胞は、NK細胞との共通の前駆細胞 $\rightarrow \mathrm{NK} \beta$ 細胞 $\rightarrow \mathrm{NKT}$ 細胞 へと分化するものと思われた。

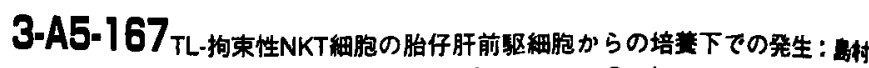

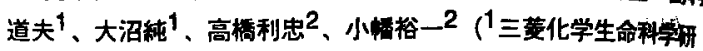
究所・細胞免废、2愛知県がんセンター研究所・兔度)

私達はマウス胎仔肝豚細胞をモノサイトーマWEHI-3およびPMA刺激し たTリンホーマEL-4の培槩上清存在下に培善することにより、NKT細胞 が発生することを報告した。この発生は抗CD1抗体添加により最大 $80 \%$ の阻害を受けたが抗MHCクラス1、クラスI、Qa2抗体添加による影翠は 受けず、ここで発生するNKT細胞の大半がCD1により正の選択を受ける ことがわかった。今回抗TL抗体（HD168、HD177）添加の発生に及活 す効果を勍べたところ最大 $10 \%$ の発生阻害を引き起こし、TLにより正の 選択を受ける少数のNKT細胞の存在が示陖された。そこでこれを証明す るため、H-2KbプロモーターをもつTL (H-2T3b) トランスジェニック

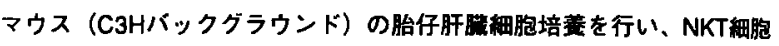
(IL-2R $\left.\beta^{+} 、 T C R \alpha \beta^{+}\right)$発生におよぼす抗TL抗体の効果を調べたとこ 万、発生は約 $35 \%$ に抑制された（この時、抗CD1抗体添加により発生は 粎65\%に減少)。さらに $\beta_{2 \mathrm{~m}}$ (-I) マウス (B6バッククランント) 胎仔

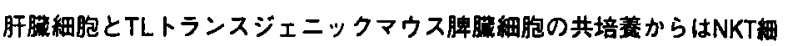
胞 (NK1.1 $\left.1^{+}, T C R \alpha \beta^{+}\right)$が発生し、これは抗TL抗体により約60\%に㧕 制されることを見出した。TLトランスジェニックマウス胎仔肝路細胞の 抗CD1抗体存在時の培算から発生するNKT細胞のV $\alpha$ 14造伝子発現は八 ントランスジェニックマウス肝仔肝茼細胞から抗体非存在下で発生する NKT細胞の約50\%に㳚少していることがRT-PCR法による定是から推測 された。以上の結果からTL-拘束性、V $\alpha 14$ のNKT細胞が培養下で存在 していることが示され、この細胞の生体内での分布、機能に興味がもた れる。

3-A5-168 NK-T細胞欠損系 aly/aly マウスと $\beta_{2} \mathrm{~m}$ ハックアウ トマウス骨㖪キメラに扔ける NK-T 細胞の分化能獲得：小西

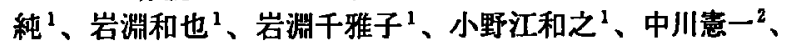
小笠原一誠 ${ }^{1}$ 、小野江和則 ${ }^{1}\left({ }^{1}\right.$ 北大·免疫研·病理、放医研 · 放射線障害医療部 - 2 研)

[目的]我↔は一昨年・昨年の本学会にて、リンパ節とパイエ ル板を欠損し、胸腺構篍に異常をもつ aly/aly マウスを用い、 同マウス環境下では、胸腺内 NK-T 細胞が出現せす、かつ脾 䁍に存在する NK-T 細胞は抗 CD3 抗体の静注後早期の I-4 産生が認められないことを報告した。今回は、aly/alyで認め られた NK-T 細胞の分化障害は、放射線抵抗性胸腺ストロー マ上の CD1 の発現とは関連しないことを証明する目的で、 $\beta{ }_{2} \mathrm{~m}$ ノックアウト（KO）マウスを宿主とした骨䯣キメラを 作製し、その NK-T 細胞の分化と機能について検索した。 [方法]骨䪔キメラマウスは、X 線照射 $\beta{ }_{2} \mathrm{mKO}$ マウスに、抗 Thy 1.2+C 処理した aly/aly 骨噵細胞を静注、作製した。in vitro での NK-T 細胞の機能は、主にプレートにコートした抗 CD3 抗体で 24 時間刺激して培盖上清中の IL-4 を、また抗 NKRP1 抗体で 48 時間刺激して、IFN- $\gamma$ を ELISA で定量すること により評価した。

[結果と考察]ドナー、宿主とも NK-T 細胞が出現しないマウ スの組み合わせである[aly/aly $\rightarrow \beta{ }_{2} \mathrm{~m}-/$ - ]キメラでは、胸腺内に 正常マウスと同程度の NK-T 細胞が認められた。また、NK-T 細胞は IL-4 産生能を有し、正常マゥス由来の NK-T 細胞と同 様の表面マーカーを示した。このことは、NK-T 細胞に必須 の分化因子が aly/aly ドナー細胞と $\beta{ }_{2} \mathrm{~m}-/$-宿主によって相㭪 的に充足されたことを示唆しているるのと考えられた。 
3-A5-169 IRF-1遺伝子欠損マウスにおけるNK-T細胞の機能 解析：小笠原康悦、肥田重明、横地妙子、佐藤健夫、谷口 維紹、瀧伸介（東京大・医・免疫)

【目的】転写因子Interferon regulatery factor (IRF-1)を欠損し たマウスではNK細胞の分化異常が認められる。我々は、昨 年本学会においてこの原因がNK前駆細胞にあるのではなく、 分化の場である骨髄微小環境の異常によるものであること、 より具体的には正-15の転写の不全を報告した。このマウス においては、NK細胞は存在しないが、NK-T細胞は少ないな がら存在する。一方で、IRF-1遺伝子久損マウス骨髄細胞を II-15と共に培養すると、NK細胞に分化し、NK-T細胞はほ とんど出現しない。これらのことは、NK-T細胞はNK細胞に 比べ、I-15の影響は受けにくいことを示していると考えら れる。今回我々は、NK-T細胞の分化、機能についてIRF-1や 几-15がどのような制御を行っているか検討するため、遺伝 子欠損マウスを用い、種々の解析を行った。

【方法】IRF-1遺伝子久損マウス、野生型マウスそれぞれ に対し、抗CD3抗体を投与した後、脾臟細胞を分離し、NKT細胞による凹-4産生能を検討した。また、【-12により誘導 されるNK-T細胞の細胞傷害活性およびがん転移抑制効果を 比較検討した。

【結果および考察】IRF-1遗伝子久損マウスにおいて、 NK-T細胞による几-4産生能は野生型マウスと比較して著明

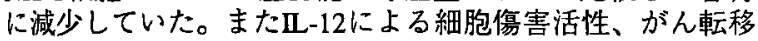
抑制効果も全く認められなかった。これらのことは、IRF-1 遺伝子欠損マウスでは、NK-T細胞はその数は減少している ものの存在するが、その機能に異常があることを示している。 現在我々は、この結果をさらに詳細に解析するため、骨䯣移 植キメラマウスを作製し、NK-T細胞機能に対する環境の影 響を検討している。

3-A5-170 ZAP-70 遺伝子久損マウスにおける NK-T 細胞の分 化幾構の解析：刀祢さ扔り ${ }^{11}$ 、岩棥千雅子 ${ }^{11}$ 、岩㴊和也 ${ }^{2}$ 、 荒浪利昌 " 、根岸 泉 ${ }^{2)}$ 、小笠原一誠 ${ }^{12}$ 、小野江和則 ${ }^{11}$

(1) 北大 ·免疫研 $\cdot$ 病理、年群大·医·皮膚)

[目的] NK-T 細胞は、T細胞レセプターと、NK 細胞のマーカ 一と考えられてきた NK1.1 の両分子を発現する細胞であるが、 その分化、成熟に関しては不明な点が多い。今回、我々は、胸 腺における T細胞分化が $\mathrm{CD}^{+} \mathrm{CD}^{+}$の double positive の段階で 停止することが知られている ZAP-70 遺伝子欠損マウスを用いて、 NK-T 細胞の分化機構について、検討した。

[万法] ZAP-70 遺伝子久損マウス、正常マウスそれぞれから胸 腺細胞を分離し、細胞表面マーカーを FACS により解析した。 さらに、胸腺器官培養系 (neonatal thymus organ culture) を用いて、 $\mathrm{Ca}^{2+}$ イオノフォア ionomycin とプロテインキナーゼC(PKC) 活性 化剠 phorbol myristate acetate (PMA) により、NK-T 細胞の分化が 誘導されるか調べた。

[結果および考察］ ZAP-70 遺伝子久損マウスに扔いては、胸 腺内 NK-T 細胞は認められず、NK-T 細胞の胸腺内分化に ZAP70 が必須であることが明らかとなった。また、NK-T 細胞は認 められなかったが、TCR NK1.1+のポピュレーションが存在し、 このポピュレーションは NK 細胞とは異なる特徵的な細胞表面 マーカーを発現し、NK-T 細胞の前駆細胞と考えられた。胸腺器 官培養系に扔いて、NK-T 細胞と考えられるポピュレーションが 誘導されたが、このポピュレーションが正常マウスにおいて胸 腺内に存在する NK-T 細胞と同一の細胞であるか、現在検討中 である。
3-A5-171 NK-T細胞の補体感受性方進メカニスムの解析： 岩㨽和也、岩㨽千雅子、小野江和之、小西 純、小笠原一 誠、小野江和則 (北大·免疫研・病理)

[目的] 我々は、NK-T細胞の機能解析を目的として、抗体と 補体処理を行う過程で、ウサギ補体 (C) 単独処理群におい てもNK-T細胞の減少することを観察した。今回このNK-T細 胞の補体感受性に関与する因子について解析した。

[方法] 主にC57BL/6 (B6)、一部では血清中の抗体の影響を除 外する目的でRAG-1-1-TCR（ニワトリ卵白アルブミン特異的 I-Ad拘束性でKJ1-26（抗クロノタイブ抗体）陽性）トランス シェニックマウス（Tgm）を用いた。これらの胸腺・脾細胞 を5 x $107 / \mathrm{ml}$ に調整し、C添加メアイウム $(\mathrm{C}(+))$ あるいはメ ディウムのみ $(\mathrm{C}(-))$ で $37^{\circ} \mathrm{C} 、 30$ 分間培盖した。冷メディウ ムで洗浄後、細胞数を計測した。さらに、各種（抗CD4 - 抗 CD8 - 抗NK1.1・抗TCR $\alpha \beta \cdot$ 抗ク口ノタイブ抗体で染色 後フローサイトメトリー解析を行い、各細胞分画の実数を算 出、比較した。

[結果と考察] B6由来の胸腺・脾細胞を用いた実験から、C()群とC(+)群の間では、CD4/8プロフィールやThy1発現バター ンに大きな変化は認められなかったが、NK-T細胞分画が有 意に隇少しており、特に胸腺で顕著であった。このNK-T細 胞の減少は、NK-T細胞は存在するが抗体は存在しないRAG1-1/TCR Tgmでは認められなかった。このことから、C処理 後のNK-T細胞の減少は、既に何らかの形でNK-T細胞に結合 している抗体が、ウサギC传存性にNK-T細胞を溶解するため と考えられた。この現象は自己免疫疾患でのNK-T細胞減少 に関連する可能性が示唆された。

[会貝外共同研究者：葛西瑞穗（北大·医·循㻴器内科）]

\section{3-A5-172}

ZAP-70 ノックアウトマウスにおける NK およ び NK-T 細胞の機能解析：岩渕 千雅子 ${ }^{1}$. 岩㴊 和也 ${ }^{1}$. 刀称さ㧈り ${ }^{1}$. 伊藤 大鿆 ${ }^{1}$. 根岸 泉 ${ }^{2}$. 小笠原一諴 ${ }^{1}$. 小野江 和則' ('北大·免疫研・病理、群大・医・皮周)

【目的】ZAP-70は CD3ら鎖に結合し、TCR からのシグナル を下流へ伝えるチロシシキナーゼて、T細胞の分化・活性化に 不可欠な分子として胸腺細胞、末梢 $\mathrm{T}$ 細胞および $\mathrm{NK}$ 細胞に 発現される。我々は ZAP-70 ノックアウトマウスにおいて NK-T 細胞と、TCR は発現していないが $\mathrm{NK}$ 細胞の出現パターンを解析した。その結果、胸腺・脾 缄では NK-T 細胞が認められないこと、一方胸腺内で NK 様 細胞の著明な增加がみられることが判明した（本学会、刀 妳・岩渆ら)。そこで、ZAP-70 ノックアウトマウスで增加 している胸腺内 NK 様細胞が、NK 細胞機能を有しているの か、末梢の NK 細胞には機能異常がないのかを検討したので 報告する。

[方法]ZAP-70+マウスど+（または+゙）マウスの胸腺細胞と 脾細胞を抗 CD3 抗体で刺激し、II-4 産生能を測定した。 た、抗 NK1.1 抗体刺激による INF- $\gamma$ 産生を測定した。さら に、YAC-1 細胞を標的とした細胞傷害活性を ${ }^{{ }^{1}} \mathrm{Cr}$ 放出試験 で測定した。

【結果および考察】ZAP-70ナマウスでは1）抗 CD3 抗体刺 激による I-4 産生は胸腺細胞および脾細胞で全く認められ なかった。2) 抗 NK1.1 抗体刺激による INF- $\gamma$ 産生はわず かに低下していた。3) YAC-1 細胞に対する細胞慯害活性は 保持されていた。

以上のことより、NK-T細胞が存在しないことが機能的に も証明された。またNK1.1を介する刺激伝達系に異常があ ることから、この経路にZAP-70が関与することが示晙され た。一方、細胞傷害活性には ZAP-70は関与しないことが判 明した。 
3-A5-173 Critical role of LFA-1 in liver migration of CD4+NK $T$ cells : Masashi EMOTO1, Hans-Willi MITTRÜCKER ${ }^{1}$, Rudolf SCHMITS ${ }^{2}$, Tak W. MAK ${ }^{3}$, Stefan H. E. KAUFMANN 1

('Dept. Immunol., Max-Planck-Inst. Infect. Biol., ${ }^{2}$ Med. Dept., Univ. Saarland, ${ }^{3}$ Dept. Med. Biophys. Immunol., Ontario Cancer Inst. \& Amgen Inst.)

In contrast to peripheral lymphoid organs, a high percentage of $T$ cells in the liver belongs to the $\mathrm{CD} 4{ }^{+} \mathrm{NK} T$ cells. To elucidate the mechanism by which $\mathrm{CD} 4^{+} \mathrm{NK} \mathrm{T}$ cells reside in the liver, we examined the impact of different adhesion molecules on migration of this cell population to the liver. $\mathrm{CD}^{+} \mathrm{NK} \mathrm{T}$ cells in the liver expressed ICAM-1 and high levels of LFA-1. In the liver of LFA-1-deficient gene knockout mice, the number of $\mathrm{CD}^{+}{ }^{+} \mathrm{NK} \mathrm{T}$ cells was markedly decreased. This reduction was restricted to the liver and no reduction in the proportion of $\mathrm{CD} 4{ }^{+} \mathrm{NK} \mathrm{T}$ cells was found in all other organs analyzed. In contrast, the number of $\mathrm{CD}^{+} \mathrm{NK} \mathrm{T}$ cells in the liver of mice deficient in ICAM-1 was only marginally reduced. These results demonstrate the crucial role of LFA-1 in the migration of $\mathrm{CD} 4+\mathrm{NK} \mathrm{T}$ cells to the liver.
3-A5-175 in vivo での IL-12 の作用における NK1 ${ }^{+} \mathrm{T}$ 細胞の 役割 : 竹田和由 ${ }^{1,2}$, 川村俊彦 ${ }^{3}$, 川村宏樹 ${ }^{3}$, 安保徹 ${ }^{3}$, 八木田秀雄 ${ }^{1,2}$, 奥村康 ${ }^{1,2}$ (順天堂大 · 医 - 免疫 ${ }^{1}, \mathrm{CREST}^{1,2}$, 新潟大·医·医動物 ${ }^{3}$ )

【目的】我々は、IL-12 の投与により $\mathrm{NK}^{+}{ }^{+} \mathrm{CD}^{+}$の $\mathrm{NK}^{+}{ }^{+} \mathrm{T}$ 細 胞に細胞傷害活性やIFN- $\gamma$ の産生が誘導されることを報告し てきた。今回、 $N K 1^{+} \mathrm{T}$ 細胞の IL-12 レセブターの発現の確䛊 と、CD1-マウスを用いての解析を行ったので報告する。 【方法】 mIL-12 の投与前後の C57BL/6 マウスの肝䐘加ら単 核球を採取し、Sorting により各リンパ球分画を分離、RT-PCR 法により IL-12 レセプター等の発現を比較した。一方、抗 AsGMI 抗体を前投与し NK 稩胞を除去した CD1トマウスに $\mathrm{mIL}-12$ を投与し、 $\mathrm{NK}$ 細胞と $\mathrm{NK} 1^{+} \mathrm{T}$ 細胞の役割を評価した。 【結果】1)Sorting 後の RT-PCRにより NK I ${ }^{+} \mathrm{T}$ 細胞に、最も強 くIL-12Rß1,B2が発現していること、IL-12 投与により perforin の発現が誘導されることを確認した。2) NK1 ${ }^{+} \mathrm{T}$ 細胞が極めて 少ないCD1-トマウスでは、IL-12 の投与により誘導される免疫 反応が CD1+/+マウスの 1/2-1/3 程度に抑制されており、その 残存する反応のほとんどが $\mathrm{NK}$ 細胞の除去により消失した。 【考察】IL-12レセプターを最も強く発現している $\mathrm{NK}^{+}{ }^{+} \mathrm{T}$ 勫 胞が、IL-12 に対する first responderであり、かつその反応の 中心となっている可能性が示唆されたが、正常な生体の IL-12 の反応にはNK 細胞も強く関与していることが示された。
3-A5-174 $\mathrm{CDA}^{+} \mathrm{NKT}$ 細胞におけるCD4OL発現能及びAPCによ るIL-12産生誘導能. : 戸村道夫'、于文功1、安賢鍾!、濱岡利之'、

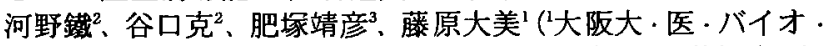

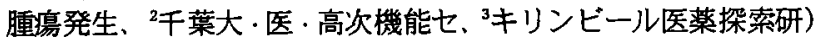

【目的】IL-12㤝、class II MHC拘束性 $\mathrm{CD} 4^{+} \mathrm{T}$ 細胞上に発現誘導 されるCD40LによりCD40 APCが刺激される時、APCから産生 される。一方、 $\mathrm{CDA}^{+} \mathrm{T}$ 細胞以外のリンバ系細胞、とりわけ Th1/Th2分化に関与すると考えられるNKT細胞がIL-12産生を刺 激する能力があるか否かは明らかではない。本研究はTCR刺激 後のNKT細胞がCDAOLを発現するか、さらにはAPCによる IL-12産生を刺激するか否かを解析することを目指した。

【万法】V $\alpha 14^{+} \mathrm{NKT}$ 細胞のTCRを特異的に刺激する抗原とし て、APCのCDIdによって提示される $\alpha$ Galactose ceramide $(\alpha \mathrm{GalCer})$ を用いた。C57BL6系マウス脾細胞のB細胞除去画分 を $\alpha$ GalCerにより刺激し、培養上清中のIL-12はAb-capture assay で、CD40L発現はFACSCaliburで検出した。

【結果·考察】(1)B細胞除去画分を $\alpha \mathrm{GalCer}$ で刺激するとIL-12 産生が認められた。(2) a GalCer刺激によるIL-12産生はV $\alpha 14^{+}$ NKTの存在しないclass $\mathrm{I}^{--}\left(\beta 2 \mathrm{~m}^{--}\right)$及びV $14^{+} \mathrm{NKT}^{-\digamma}\left(\mathrm{J} \alpha 281^{-1}\right)$ マウ

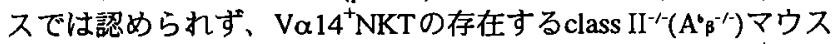
で認めれたことから、 $\alpha$ GalCerによるIL-12産生にはV $\alpha 14^{+} \mathrm{NKT}$ が必要であった。(3)aGalCerによるIL-12産生は、抗CD4OL抗体の 添加で吅制された。(4)抗CD3抗体又は $\alpha$ GalCer刺激後のCD40L発 現は、CD4+NKTでは高頻度に誘導される一方、CD4NKTでは ほとんど認められなかった。また、 $\mathrm{CD}^{+}{ }^{+} \mathrm{NKT}$ を除去すると aGalCerによるIL-12産生は検出できなかった。

以上、本研究より $\mathrm{CDA}^{+} \mathrm{T}$ 細胞に加え、NKT細胞もIL-12産生 刺激につながるCD40L発現能を有すこと、更に興味深いことに NKT細胞集団の中でもCD4 ${ }^{+} \mathrm{NKT}$ 細胞亜集団により、選択的に その機能が担われていることが明らかとなった。
3-A5-176 マウスのサルモネラ感染症で誘導されるNK1.1陽

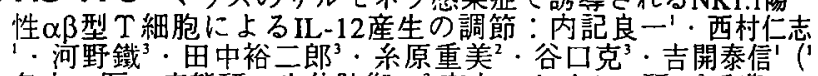
名大. 医·病態研・生体防御、涼大・ウイルス研、故葉 大·院・免疫発生)

【目的】マウスのサルモネラ感染症において、腹腔内にNK1.1 陽性 $\alpha \beta$ 型 T 細胞が增加し、多量のIL-4を産生することを報告 した。本研究では、サル主京感染症で出現する丁ヘルパ 1 型 (Th1) 応答におよはす寸NK1.1陽性 $\alpha \beta$ 型T細胞の役割を明 らかにするため、NK1.1陽性 $\alpha \beta$ 型T細胞欠摃マウスにサルモネ ラを感染させ、正常マウスと比較した。【方法】T細胞レセ

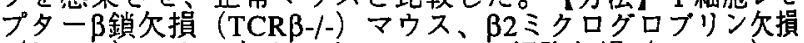

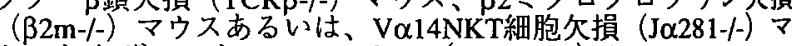
ウスおよびコントロールマウス (C57BL/6) kSalmonella choleraesuis 31N-1株を腹腔感染させ、感染 6 日目の腹胫細胞加 ら単離したT細胞を、サルモネ开死菌（HKS）あるいはTCR

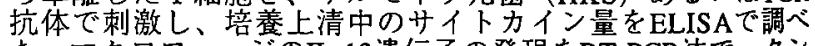
た。マクロフフージのI-12遺伝子の発現をRT-PCR法で、タン パク質レベルでの産生をELISAで調べた。コントロールマウス にanti-IL-4中和抗体を腹腔内投与した㣪、Salmonellat感染さ せ、IL-12産生に及ほす影響を調べだントロールマウス加 らNK1.1陽性 $\alpha \beta$ 型T細胞群とNK1.1 T細胞群を調節し、それぞ れをTCRß-ーマウスヘ移入し、サルモネラ感染後の、IL-12産生

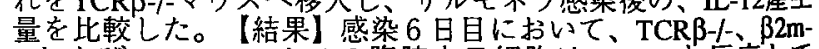

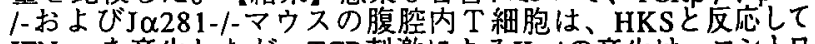
IFN- $\gamma$ を産生したが、TCR刺激によるIL-4の産生は、コシトロ ールマウス比べで著しく低下していた。またいずれの欠 損マウスにおいても、IL-12は遺伝子、タンパク質レベルとも にコントロールマウスと比較して著しく高かった。コントロ 一ルマウスにおいて産生されるIL-4をanti-IL-4中和抗体で中和 すると、II-12の産生量が著しく增加した。また、TCRß-トマク

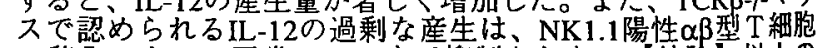
の移入によって正常レベルまで抑制された。結論】以上の 結果加ら、サル市ラ感染症で誘導されるNK1.1陽性 $\alpha$ 型T細

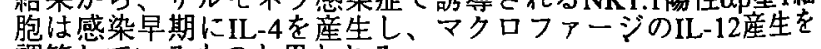
調節しているものと思われる。 
3-A5-177 サルモネラ感染症で出現する NK1.1 陽性 $\gamma \delta \mathrm{T}$ 細胞 の機能: 原 徽 ${ }^{1,2}$, 西村仁志 ${ }^{2}$, 吉開泰信 ${ }^{2}, \quad$ ('名大·医.一内 、同·病熊研・生体防御)

(目的) 我々は、マウスのサルモネラ感染症において $\gamma \delta$ 型 $T$ 細胞が初期防御に働くことを明らかにしだ。さらに $\gamma \delta$ 型 T 細 胞のうち NK1.1 分子を発現しているサブタイプが存在してい ることを見いだした。NK1.1 陽性 $\gamma \delta$ 型 T 細胞はその MHC 拘 束性や T 細胞レセプターレパートアーの違いなどから、他の $\gamma \delta$ 型 $\mathrm{T}$ 細胞とは異なった機能を持つものと推測される。今回、 マウスのサルモネラ感染症で出現する NK 1.1 陽性 $\gamma \delta$ 型 T細胞 の機能について検討を行った。

(方法) C57BL/6 マウス、 $\beta 2 \mathrm{~m}-\%$ (MHC class I) 遺伝子久損 (KO)マウス、拉よび A $\beta$-/-(MHC class II)KO マウスに Salmonella choleraesuis $31 \mathrm{~N}-1$ 株を腹腔感染させて 6 日目の 腹腔細胞を探取し NK1.1 陽性 $\gamma \delta$ 型 T細胞の出現を FACScan で比較した。また腹腔細胞より T細胞を精製し、パニング法 にて $\gamma \delta$ 型 $\mathrm{T}$ 細胞を単離した。 $\mathrm{T}$ 細胞の刺激には非感染マウス の脾細胞を 24 時間 PHA で処理をしたものを用いて反応性を 調へた。 $\gamma \delta$ 型 $\mathrm{T}$ 細胞の反応性は $3 \mathrm{H}$-チミジンの取り込みで評 価した。また刺激後の培養上清中の各種サイトカインの産生 量を ELISA 法にて測定した。

(結果及び考察) サルモネラ感染で誘導される $\gamma \delta$ 型 $\mathrm{T}$ 細胞の うち、NK1.1 陽性 $\gamma \delta$ 型 T 細胞は C57BL/6 マウスでは約 $15 \%$ であった。一方、A $\beta$-KO マウスではほとんど出現が認めら れず、 $\beta 2 \mathrm{~m}-1-\mathrm{KO}$ マウスではむしろ増加していた。NK1.1 陽 性 $\gamma \delta$ 型 $\mathrm{T}$ 細胞は自己の脾臓細胞と強い反応性を示し、IFN- $\gamma$ およびMCP-1の産生が認められた。しかし IL-4の有意な産生 は見られなかった。これらのことから、NK1.1 陽性 $\gamma \delta$ 型 $\mathrm{T}$ 細 胞はマウスのサルモネラ感染症の初期免疫応答において、他の 炎症性細胞の動員や活性化に関与しているものと推測される。

\section{3-A5-178 Dependence of LPS-induced cytotoxicity of} liver $\mathrm{NK}^{+} \mathrm{T}$ cells on $\mathrm{NK}$ cells : Yoshiko HABU ${ }^{\prime}$, Shuhji SEKI', Hiroshi DOBASHI ${ }^{2}$ and Hoshio HIRAIDE' ('Div. Basic Traumatol. , Nat. Def. Med. Coll. Res. Ins. , ${ }^{2}$ Dept. Pediatr., Nat. Def. Med.Coll.)

We previously reported that LPS or IL- 12 injection into mice induce a portent anti-tumor cy totoxicities of liver $\mathrm{NK} 1^{+} \mathrm{T}$ cells and these cytotoxicities are dependent on IFN- $\gamma$ induced by IL-12. However, the present study demonstrates that LPS-induced cytotoxicity of liver NK $1^{+}$ $T$ cells is completely abrogated by the in vivo depletion of NK 1 cells by anti-asialoGMI Ab, whereas IL-12-induced cytotoxicity of liver $\mathrm{NK}^{+} \mathrm{T}$ cells is not affected by the NK cell depletion. Sorting experiments revealed that NK cells produce a grater IFN $-\gamma$ amounts than $\mathrm{NK}^{+} \mathrm{T}$ cells by the stimulation of LPS, whereas $\mathrm{NK}^{+} \mathrm{T}$ cells produce more IFN- $\boldsymbol{\gamma}$ than NK cells by IL-12. However, NK $1^{+} \mathrm{T}$ cells have more potent anti-tumor cytotoxicity than NK cells either by LPS or IL-12 injections. Further, LPS could not induce a significant cy totoxicity to $\mathrm{NKI}^{+} \mathrm{T}$ cell deficient $\beta_{2}$-microgloblin -/-mice. Therefore although both LPS and IL-12 confer potent cytotoxicities to $N \mathrm{~K}^{+} \mathrm{T}$ cells, the presence of NK cells is essential for LPS-induced cytotoxicity of $\mathrm{NK}^{+} \mathrm{T}$ cells in the liver. Puzzlingly, however, exogenous IFN- $\gamma$ could not recover reduced cytotoxicity of liver MNC of NK cells depleted and LPS injected mice. A futher analysis is now underway.
3-A5-179 Requirement of both IL-4 and IFN- $\gamma$ for concanavalin A-induced hepatic injury of mice: Tetsuro NISHIKAGE ${ }^{\mathfrak{l}}$, Shuhji SEKI ${ }^{1}$, Shinichi TOYABE ${ }^{2}$, Toru $\mathrm{ABO}^{2}$, Hoshio HIRAIDE' ('Div. Basic Traumatology, Nat. Def. Med. Coll. Res. Inst., ${ }^{2}$ Dept immunology, Niigata Univ.)

LPS pretreatment ( $\geq 500 \mathrm{ng} /$ mouse, i.p.) markedly decreased serum IL-4 elevation and hepatic injury, whereas LPS pretreated mice showed severe hepatic injury if exogenous IL-4 was administered shortly before ConA injection. Anti-IL-6Ab injection shortly before LPS pretreatment greatly inhibited the protective effect of LPS on hepatic injury and upregulated serum IL-4 levels after ConA injection. IL-6 pretreatment but not IL-10 nor IL-12 pretreatment suppressed ConA induced IL-4 production and hepatitis. Either anti-IFN- $\gamma \mathrm{Ab}$ or anti-IL-4Ab almost completely inhibited ConA hepatitis. Interestingly,anti-IFN- $\gamma$ Ab unexpectedly inhibited the ConA-induced elevation of serum IFN$\gamma$ and IL-4 levels, whereas anti-IL-4Ab did not inhibit elevation of serum IFN- $\gamma$ levels. Cell sorting experiments confirmed that IL-4 producing cells in the liver affected by ConA stimulation are NK $1^{+} \mathrm{T}$ cells, while IFN- $\gamma$ producing cells are both $N K 1^{+} \mathrm{T}$ cells and NK 1 T cells. Further, IL-4 mutant mice did not develop ConA hepatitis despite the fact that they have NK1.1 ${ }^{+} \mathrm{T}$ cells in the liver. Our findings reveal that LPS inhibits ConA-induced hepatitis by inducing IL-6 production and thereby inhibiting IL-4 synthesis of $\mathrm{NK} 1^{+} \mathrm{T}$ cells, and that both IL-4 and IFN $-\gamma$ are required for ConA-induced hepatic injury.

3-A5-180 The role of $\mathrm{NK}$ cells and $\mathrm{NK} 1^{+} \mathrm{T}$ cells in superantigen induced response in mice: Hiroshi DOBASHI', Shuhji SEKI ${ }^{2}$, Takashi OHKAWA', Seiichiro TAKESHITA, Yoshinori TAKATA, Yoshiko HABU, Hoshio HIRAIDE, Isao SEKINE' ('Dept. Pediatr. Nat. Def. Med. Coll., ${ }^{2}$ Div. Basic Traumatol., Nat. Def. Med. Coll. Res. Inst.)

Although superantigens are known to be powerful T cell stimulants, and induced systemic inflammatory responses such as toxic shock like syndromes, the roles of NK cells and $\mathrm{NK} 1^{+} \mathrm{T}$ cells are largely unknown. 4h after injections of SPE-A $(10 \mu \mathrm{g})$ or SEB $(50 \mu \mathrm{g})$, MNC of liver, spleen, lung and peripheral blood were obtained and cultured 48h. Hepatic MNC produced much more IFN- $\gamma$ than MNC of other organs. IFN- $\gamma$ productions were reduced if mice had been pretreated with anti-asialo GM1 (AGM1) Ab or anti-NK1 Ab to deplete NK cells alone or both NK cells and NK $1^{+} \mathrm{T}$ cells. However, $\mathrm{NK}$ cells and $\mathrm{NK} 1^{+} \mathrm{T}$ cells depleted hepatic MNC produce a substantial amount of IFN- $\gamma$ if cultured for longer periods $(72 \mathrm{~h}$ and 96h). Consistent with that, serum IFN- $\gamma$ levels of these $\mathrm{Ab}$ pretreated mice were significantly decreased, cytotoxic assays revealed superantigen induced strong anti-tumor cytotoxicities of liver MNC, whereas depletion of NK cells alone partly decreased the cytotoxicity and depletion of NK cells and $\mathrm{NK}^{+}{ }^{+} \mathrm{T}$ cells abolish the cytotoxicity of liver MNC. Our data suggest that NK cells and $\mathrm{NK} 1^{+} \mathrm{T}$ cells are activated in the initial phase of the superantigen induced responses, and $\mathrm{T}$ cells are activated thereafter. Therefore systemic inflammatory response induced by bacterial superantigens cannot be precisely understood without consideration of NK cells and NK $1^{+} \mathrm{T}$ cells. 
3-A5-181 $\mathrm{CD}^{-1} \mathrm{~T}$ cells as well as CD56 ${ }^{+} \mathrm{T}$ cells have much grater IFN- $\gamma$ production and cytotoxic activities than CD56 CD57 $\mathrm{T}$ cells : Takashi OHKAWA ${ }^{1}$, Shuhji SEKI ${ }^{2}$, Hiroshi DOBASHI ${ }^{1}$, Yoshiko HABU $^{2}$, Seiichiro TAKESHITA', Hoshio HIRAIDE ${ }^{2}$, Isao SEKINE'. ('Dept. Pediatr., Nat. Def. Med. Coll., Div. Basic Traumatol., Nat. Def. Med. Coll. Res. Inst.)

NKT cells, both $\mathrm{CD} 57^{+} \mathrm{T}$ cells and $\mathrm{CD} 56^{+} \mathrm{T}$ cells, have been considered to differentiate through a extrathymic pathway and are distinguishable from conventional thymic T cells. However, The functions of these NKT cells are not completely understood. In this study, to elucidate the function of these cells, we examined their productions of INF- $\gamma$ and anti-tumor cytotoxic activities and compared with those of CD56 CD57 ${ }^{\circ} \mathrm{T}$ cells. Sorted CD56 ${ }^{+} \mathrm{T}$ cells, $\mathrm{CD}^{\circ} 7^{+} \mathrm{T}$ cells and $\mathrm{CD} 56^{-} \mathrm{CD} 57^{-} \mathrm{T}$ cells were cultured in the presence of anti-CD3 Ab with or without IL-2, IL-12 and IL-15. The IFN- $\gamma$ levels of culture supernatants for 48 hours without IL-2, IL- 12 and IL-15 were higher in $\mathrm{CD}^{+} 7^{+} \mathrm{T}$ cells as well as $\mathrm{CD}^{+} \mathrm{T}$ cells than those in CD56 CD57 $\mathrm{T}$ cells. With these cytokines, however, IFN- $\gamma$ production of CD56 CD57 $T$ cells was the highest among three groups of $\mathrm{T}$ cells. On the other hand, the cytotoxity of $\mathrm{CD}^{+} 7^{+} \mathrm{T}$ cells and $\mathrm{CD} 56^{+} \mathrm{T}$ cells 7 days after ant-CD3 $\mathrm{Ab}$ stimulation were much grater than that of $\mathrm{CD} 56 \mathrm{CD} 57^{\circ} \mathrm{T}$ cells with or without cytokines. These results reveal that $\mathrm{CD} 57^{+} \mathrm{T}$ ells as well as $\mathrm{CD}^{+} 6^{+} \mathrm{T}$ cells can secrete Th 1 type cytokines and act as antitumor effectors via a TCR stimulation, and the increase of $\mathrm{CD}^{+}$ $T$ cells and their IFN- $\gamma$ production are closely related to the immunological change with aging.

\section{3-A5-182} 7 xenografts in mice: Kazuhiko SATO ${ }^{1}$, Shuhji SEKI ${ }^{2}$, Tetsuro NISHIKAGE ${ }^{2}$, Yoshiko HABU ${ }^{2}$, Hiroshi DOBASHI ${ }^{3}$, Hoshio HIRAIDE ${ }^{2}$, Hidetaka MOCHIZUKI ${ }^{1}$ (Surg. I' ${ }^{1}$ \& Pediatr. ${ }^{3}$ Nat. Def. Med. Coll. Div. Basic Traumatol. Nat. Def. Med. Coll. Res. Inst. ${ }^{2}$ )

The aim of this study was to assess the role of extrathymic Tcells of mice in suppressing human breast cancer cell line, MCF-7. BALB/C nude mice had been treated with either anti-asialo GM1(AGM1)Ab

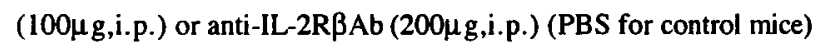
on day -4 to deplete NKcells alone or NKcells and extrathymic $T$ cells (IL-2R $\beta^{+}$intermediate TCR). 10 mice of each group were s.c. inoculated with $5 \times 10^{6}$ MCF-7 cells on the back and estradiol $\left(E_{2}\right)$ was i.m. injected every 7 days 3 times from day 0 . In other experiments, mice pretreated with either Ab or PBS were injected with $0.5 \mu \mathrm{g}$ IL-12(i.p.) 1 day before sacrifice and anti-tumor cytotoxicity of liver and spleen MNC against MCF-7 and ELA cells were examined by the ${ }^{51} \mathrm{Cr}$ assay. MCF-7 cells were successfully implanted in 2 mice of control mice, 4 mice in AGM1 Ab treated mice and all of IL-2R $\beta A b$ treated mice. Liver MNC of IL-12 injected control mice killed $20 \%$ EL4 cells and $5.3 \%$ of MCF-7 cells while the cytotoxity of liver MNC of NKcell depleted mice was partially decreased and that of NKcell and Tcell depleted mice was arrogated. Cytotoxisities of splenocytes were not significantly different among mouse groups, probably because the spleen has fewer NKcells and Tcells than the liver. Our findings suggest that not only NKcells but also extrathymic Tcells are responsible for the rejection of MCF-7 and the role of extrathymic T cells (CD56 ${ }^{+}$or $\mathrm{CD} 57^{+} \mathrm{Tcells}$ ) should be considered in humans.
3-A5-183

熙*，河野抗原特異的IgE産生抑制：崔俊青、渡边直 疫発生、慈恵医大・熱帯医学*)

【目的】抗原特異的IgE産生抑制があることは、古くから知 られていたが、その本態についての解明はなされていなか つた。最近になって注目されているNKT細胞は、刺激によ つて大量のIL-4やIFNyを産生する。IgEの産生には、Th2細 胞の産生するIL-4が重要であるが、NKT細胞の産生するIL-4 やIFNyはTh2細胞の分化についてはそれぞれ、増強、抑制す ると考えられている。ここでは、抗原特異的IgE産生抑制の 本態を明らかにすることを目的とした。

【方法、及び結果】正常B6マウス、NKT欠損マウス、 IFN $\gamma$ 欠損マウスに、DNP-OVAをAlumを用いて免疫し、2 週 間後、3 週間後、さらに、DNP-OVAで再感作したのちの 1 週間後に血清中のDNP特異的IgE産生をELISAにて検索し た。正常B6マウス、NKT損マウス、IFN $\gamma$ 欠損マウス共に 同じレベルのDNP特異的IgEを産生していた。次に、我々 が、昨年同定したNKT細胞のTCRのリガンドである $\alpha-$ GalCerをマウスに投与することによって生体内でNKT細胞 を活性化し、DNP-OVA免疫によって誘導される血清中の DNP特異的IgE産生の変化を検討した。 $\alpha$-GalCerをマウスに 投与した場合、正常B6マウスではDNP特異的IgE産生が激減 したが、Th1依存性のアイソタイプであるIgG2aに変化はみ られなかった。この抗原特異的IgE産生抑制はNKT欠損マウ スやIFN $\gamma$ 欠損マウスでは見られなかった。

【結論】これらの解析から、抗原特異的IgE産生抑制には NKT細胞が関与していること、さらにIFN $\gamma か ゙$ 関与している ことが示唆された。抗原感作時にどのようにしてNKT細胞 が活性化され、抗原特異的IgE産生を調節しているのか、現 在検討している。
3-A5-184十全大補湯の経口投与によるマウス肝における サイトカイン産生の調節と NKT 細胞の誘導：松本 司 (北里 研・東洋医学総研)

【目的】肝臓には比較的多数の免疫担当細胞が存在すること が知られている。肝臓は腸管から吸収された薬效物質が最初 に相互作用する臟器であることから、肝臓は漢方薬の薬効発 現においても極めて重要な臟器の一つと考えられる。今回、 肝リンパ球に及ほす作用について検討を行った結果、漢方方 鼡の一つである十全大補湯がサイトカイン産生を調節すると ともに、NKT 細胞を誘導することを見出したので報告する。 【方法】実験動物：C57BL/6マウスを用いた。被検薬物：自家 製の十全大補湯拈よび市販の十全大補湯エキス原末 [TJ-48, （株）ツムラより供与]を用いた。リンパ球の調製：脱血し たマウスの肝臓を金属メッシュ上でほぐし、ヘパリン存在下 におけるパーコール遠心法により調製した。リンパ球表面マー カーの分析：蛍光標識抗体で染色した後に、フローサイトメー ターで分析した。サイトカイン量の測定：刺激物質の存在下 にリンパ球を 2 日間培盖し、得られた培養上清中のサイトカ イン量を ELISA 法により測定した。

【結果拉よ゙考察】マウスに十全大補湯エキスを 2 週間連日 経口投与後、肝リンパ球を調裂し産生される各種サイトカイ ン量を測定した。その結果、十全大補湯エキスの経口投与に より、IFN- $\gamma 、$ IL-4 、IL-5 および IL-6の産生能は著明に元進し たが、IL-2 の産生能は低下した。肝リンパ球をFCMにより分 析した結果、十全大補湯エキスの投与により NKT細胞 $\left(\mathrm{CD}^{\text {int }} \mathrm{NK} 1.1^{+}\right)$が $1.5 \sim 2$ 倍に増加することが明かとなった。

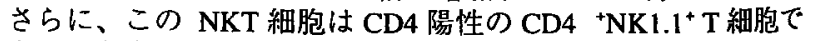
あることも明かとなった。NKT 細胞は、各種サイトカインの 高い産生能を有する他、ガンの転移抑制や自己免疫疾患の発 症抑制に関与することも示唆されており、十全大補湯の薬効 にNKT 細胞の誘導が関与する可能性が推定された。 非会員共同研究者：櫻井真澄、清原寛章、山田陽城 
3-A5-185 ループス腎炎発症 W/BF1 マウスにおける NK1.1+ 細胞の解析：增永太郎（藤沢薬品工業（株）・薬理研）

【目的】近年、ヒトおよび動物において NK, NKT（NK1.1+） 細胞が自己免疫疾患を抑制的に制御していることが明らかに なりつつある。今回、我々はループス腎炎の発症を NK1.1+ 細胞が抑制的に制御しているか否かを明らかにするため、早 期に重篤なループス腎炎を自然発症する $(\mathrm{NZW} \times \mathrm{BXSB}) \mathrm{F} 1$ (W/BF1) マウスを用いて検討した。

【方法および結果】W/BF1 マウスでは、血中抗 dsDNA 抗体 価および尿中アルブミン量を指標としたループス腎炎の発症 は 9 週粭加認められ、加齢とともに悪化した。この時の脾 細胞をFACSにより解析したところ、ループス腎炎の発症に 伴って NK1.1+細胞の割合の滅少が認められた。更に、抗 CD3 抗体誘発 IL-4 産生反応および Yac-1 細胞傷害反応により NK1.1+細胞の機能について検討したところ、ループス腎炎発 症マウスでは IL-4 産生量およびYac-1 障害活性ともに顕著に 低下しており、機能面からもNK1.1+細胞の減少が確認された。 この NK1.1+細胞の減少がループス腎炎の発症の直接の原因 であるか否かを見極めるため、5 週龄から抗 NK1.1 抗体を投 与することにより NK1.1+細胞除去試験を行った。NK1.1+細 胞除去はループス腎炎の発症に何ら影響を与えなかった。 【結論】W/BF1 マウスではループス堅炎の発症に伴って $\mathrm{NK} 1.1+$ 細胞の減少が認められるものの、このことがループス 腎炎発症の直接の原因ではないことが示唆された。

3-A5-186 NKT 細胞洁自然免疫之獲得免疫の橋渡しをする免 疫調節細胞である: 北村秀光 ${ }^{1,2} 、 太$ 田明夫 ${ }^{1} 、 八$ 幡 崇 $^{1,3}$ 、岩 壁賢治 ${ }^{1,3}$ 、大見 寧 ${ }^{1}$ 、佐藤まりも ${ }^{1}$ 、竹田和由 ${ }^{4}$ 、奥村 康 ${ }^{4}$ 、 河野 鐵 ${ }^{5}$ 、谷口 克 ${ }^{5}$ 、西村孝司 ${ }^{1,3}$ 、 ( ${ }^{1}$ 東海大・医 - 遺伝子 工学、 ${ }^{2}$ 北大院·理 - 生体設計、 ${ }^{3}$ 東海大·医·免疫、順大 - 医· 兔疼、 ${ }^{5}$ 千葉大・院・兔疫発生)

[目的] 自然免疫と獲得性免疫反応がどのように進行し、いか なる機構によって前者から後者への移行が起こるかに関しては 不明である。我々は今回、NKT 細胞のターゲット分子である a-グリコシルセラミド(KRN7000)を用いて NKT 細胞が自然 免疫から獲得免疫への移行に不可欠な免疫調節細胞であること を初めて証明したので報告する。

[方法および結果］ KRN7000( $2 \mu \mathrm{g} /$ mouse)を C57BL/6 マウ スに静脈内投与することによって、4 時間以内に血中サイトカ インの上昇、脾細胞中の NK 活性の增強、IL-12 レセプター発 現增強の他に、M $\mathrm{M} 、 \mathrm{~T}$ および $\mathrm{B}$ 細胞における初期活性化抗原 CD69 の発現増強が誘導された。この様な KRN7000による自 然免疫、獲得性免疫の活性化法共にCD1dに拘束されているこ 之が $\mathrm{CD} 1 \mathrm{~d}^{-/}$マウスを用いて証明された。さらに、V $\alpha 14 \mathrm{NKT}$ を欠損した Ja281 た KRN7000による NK 活性化、M $\mathrm{M} 、 \mathrm{~T}$ 細胞および B 細胞に おける CD69 の発現、IFN- $\gamma$ 産生および IL-12 レセプターの発 現など全ての免疫反応が誘導されなかった。従って、CD1d 拘 束的に活性化される NKT 細胞は、サイトカイン産生や細胞傷 害活性を介して自然免疫のエフェクターとして機能するだけで はなく、自然免疫と獲得免疫の bridging cell としての重要な免 疫調節を行っていることが初めて証明された。
3-A5-187 胎生中期ラット卵黄覀における0X8陽性NK様細胞の 同定：楊 少純, 森 真理子, 顧 寿智, 山下 昭 (浜松 医大·第二解剖)

マウスの胎生中期卵黄霟細胞群にNatural Cytotoxicity を発揮 する細胞が存在することが報告されたが、その細胞の表面マー カーや起源についてはまだ十分解明されていない。我々は胎生

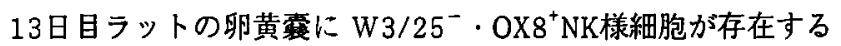
かどうかを検索した。[材料と方法] 近交系DA（RT1 $\left.1^{\mathrm{a}}\right)$ ラッ 卜の胎生13日齢の胚仔と卵黄賈を摘出し，それぞれからOCT包 埋・凍結切片標本を作成し,さらに卵黄变の細胞浮遊液を作成 LOX8,W3/25 単クローン抗体を用いてAlkaline phosphatase 間接型免疫組織化学染色を施し光顕で観察した。また細胞浮遊 液をCytospinにかけて免疫化学染色し,光顕で観察すると共に, Flowcytometry 解析を行って,細胞の表面マーカーの発現性を検 索した。[結果] 卵黄鸾の内胚葉性上皮細胞層にOX8陽性細 胞が散在的に存在した。特に胎盤近側に強陽性細胞が見られた。 胎盤，胚仔，血島では陽性所見は見られなかった。いずれも W3/25陰性であった。Cytospin 標本で,OX8 陽性細胞は不規則 な形を呈し、大型の核を有し細胞質には大小不同の空泡がしば しば観察された。Flowcytometry 解析で,OX8 陽性細胞が約13 \%存在したが、W $3 / 25$ 陽性細胞は見られなかった。[考察]胎 生13日齢ラットの卵黄賈内胚葉性上皮細胞層に免疫染色と EPICSでW $3 / 25^{-} \cdot \mathrm{OX}^{+}$細胞を検出した。その陽性細胞は形 驡学的に成体LGL或いはNK細胞類似であった。これらOX8陽性 $\left(\mathrm{CD} 8^{+}\right)$細胞は卵黄囊内でNK細胞へ分化することが示唆された。

3-A5-188 肝再生早期における NKT 細胞の增加とその役割: 皆川昌広 ${ }^{1,2}$ 、大矢洋 1,2 、清水孝王 ${ }^{1,2}$ 、坂内 誠 1,2 、安保徽 ${ }^{1}\left({ }^{1}\right.$ 新潟大·医·医動物免疫、 ${ }^{2}$ 新潟大·医・一外)

【目的】肝再生早期の残存肝中では、NK' 細胞の著增が認めら れる。今回我々は、これら NKT 細胞増加の要因の一つとしてとし て catecholamine の関与を調へるとともに、肝細胞障害活性を調 バることにより、肝再生中 NKT 細胞の役割について検討してみ た。

【方法】B6 マウスにおいて、70\%肝切除および Sham 手術を行った 後、各術後日のマウス血清中カテコラミン量を計浿した。次に、残 存肝中および脾臟のリンバ球を分傩し、フローサイトメトリーにより

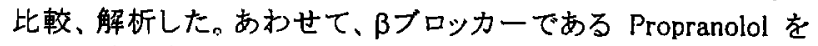
$100 \mu \mathrm{g}$ 連日皮下投与した際の変化も検討した。また、 Sortingによ 各細胞分画をえて、 $\beta$-adrenergic receptor 数を ${ }^{125}$ I-CYP 結合試 験により、測定した。さらに、正常肝細胞および再生肝細胞に対 する障害をみるため、混合培養液上清中の GOT 測定による肝細 胞障害活性試験を試みた。

【結果、考察】1)肝切除後、術後1日目まで、NKT 細胞が著明な 增加を示しており、Propranolol 投与にてこの增加が少なくなって いた。また、NK'T細胞の $\beta$-adrenergic receptor 数は、他の細胞分 画に比べ多いことが加かった。これらより、NKT 細胞增加の要因 の一つとして、カテコラミンの刺激があることが示唆された。2)残 存肝少パ球の正常肝細胞に対する障害活性は、Sham 手術群に 比べ高い一方、再生肝細胞に对する障害活性注抑制されていた。 このことから、増加した NKT 細胞は、再生中の肝細胞に対する何 らかの抑制機構をもっており、肝再生時の免疫系を制御している 可能性があると思われた。 
3-A5-189 高山英次 ${ }^{\prime}$, 関修司 ${ }^{2}$, 大川貫司 ${ }^{3}$, 土橋浩 ${ }^{3}$, 平出星夫 ${ }^{2}$, 多田隈

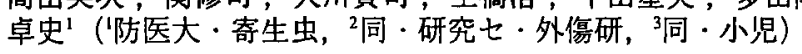

マウスにおいて、胸腺外分化CD8 ${ }^{+} / \mathrm{TCR}^{\text {intermediate }} / \mathrm{CD} 122$ (IL-2R

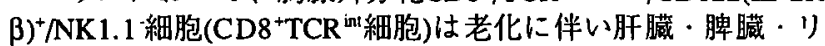
ンパ節において蓄積増加することが報告されている。この

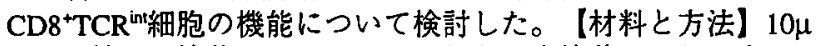
$\mathrm{g} / \mathrm{ml}$ の抗CD3抗体でコーティングした96穴培盖ディシュ上で、 6週龄と45週齢のマウス脾細胞をウェル当り $4 \times 10^{5}$ で培盖した。 また、抗CD8マグネット・ビーズを用いてCD8+細胞を除いた 脾細胞、セル・ソーターを用いて分離したCD8 ${ }^{+} \mathrm{CD} 122$ および $\mathrm{CD}^{+}{ }^{+} \mathrm{CD} 122^{+}\left(\mathrm{CD}^{+}{ }^{+} \mathrm{TCR}^{\mathrm{int}}\right.$ 細胞) 脾細胞を同樣にして培盖した。 それぞれの培養上清を48時間後回収し、IFN $\gamma$ およびIL-4産生 量を测定した。【結果と考察】CD8 ${ }^{+} \mathrm{TCR}^{\mathrm{int}} \mathrm{NKT}$ 細胞は、6週齢 の全脾細胞中に $1.8 \%$ 存在していたが、45週龄の全脾細胞中で は4.4\%に增加していた。そしてIFN $\gamma$ 産生は6週龄全脾細胞に比 べ45週齢全脾細胞では2倍以上に増加していたが、CD8+細胞を 除いた脾細胞では6週龄と45週踰いずれの場合も著しく低下し だささらに、CD8+CD $122^{+}$細胞のIFN $\gamma$ 産生は、全脾細胞に比べ、 3倍以上であったが、 $\mathrm{CD} 8{ }^{+} \mathrm{CD} 122$ 脾細胞によるIFN $\gamma$ 産生は、 $\mathrm{CD} 8^{+} \mathrm{CD} 122^{+}$細胞に比べ、著しく低かった。一方、IL-4産生は 6 週齢と45週齢いずれの全脾細胞においても同程度認められた が、CD8+細胞を除いた脾細胞では6週齢と45週龄いずれの場合

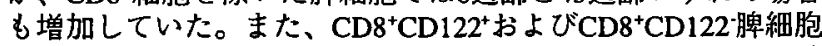
いずれにも匹-4産生はほとんど認められなかった。以上の結 果より、CD8 ${ }^{+} \mathrm{TCR}^{\mathrm{in}}$ 細胞の機能の一つとしてIFN $\gamma$ 産生が明か となり、さらにIL-4産生の抑制機能を担う可能性が示唆され た。このことは、老化に伴いTh1反応が優位となる機構に

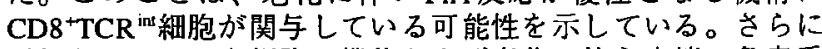
詳細な CD8 ${ }^{+} \mathrm{TCR}$ in細胞の機能および老化に伴う末梢の免疫系 の変化について検討を進めている。

3-A5-190 マウスV 14 NKT細胞を活性化する糖脂質の構造 : 鎌田憲明1、河野 鐵1、田中裕二郎1、石塚稲夫 2 、杉田陸海 ${ }^{3}$ 、 矢野郁也 ${ }^{4} 、$ 中山俊壳 1 、谷口 克 ${ }^{1}$ ( 1 千葉大院・免疫発生、 2帝京大・二生化、3滋賀大・教育、4大阪市大・細菌)

【目的】マウス $V \alpha 14 N K T$ 細胞は新しいリンパ球系列として発 見され、ただ1種類の抗原受容体（Vo14）を発現する。昨年 われわれはV $\alpha 14 N K T$ 受容体のリガンドが糖脂質のひとつであ る $\alpha$-galactosyl ceramide $(\alpha-G a l C e r)$ であることを明らかにした。

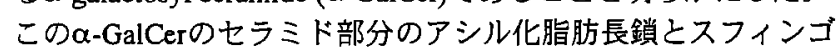
シン長鎖でCD1dの疎水性溝に結合し、CD1dのアルファヘリッ クスループと $\alpha$-GalCerの糖鎖複合体がV $\alpha 14$ 受容体によって認 識されることが示されている。今回CD1dと $\alpha$-GalCerの安定し た結合に関わる構造上の条件について検討を行なった。

【方法、及び結果】 Vo14NKTマウスの脾蔵細胞を用い糖脂質 の糖鎖、脂質の構造を変えてV $\alpha 14 \mathrm{NKT}$ 細胞の増殖能を調べた。 糖鎖ではガラクトース、グルコースの場合は反応したが

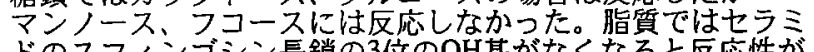

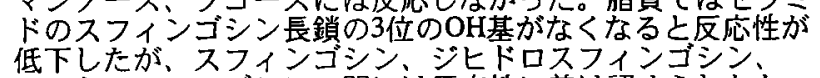
フィトスフィンゴシンの間には反応性に差は認められなかつ た。このことはセラミドをグリセロールに代えると反応が られなくなったことを一致する。GPIはCD1dに結合すること が報告されているが、V $014 \mathrm{NKT}$ 細胞を活性化することはでき なかった。

【考察】マウスV V14NKT細胞を活性化する糖脂質の構造上の 条件として糖鎖においては2、6位のOH基の位置が重要であり、 脂質の構造としてはセラミドのスフィンゴジの3位の0H基 が重要であると考えられた。これらのことから糖および脂筫 のOH基がCD1dやV $\alpha 14 N K T$ 細胞受容体との接蚛に重要な役割 を果たしていることが示唆された。GPIはCD1dに結合するが、 Va14NKT細胞を活性化できないと考えられた。
3-A5-191 っラス Ib の分子透伝学的解析 I.RT1.Nファミ リーケ゚ノム遗伝子の単離と構造解析 : 杵㴊 幸、本田党一。 陳 宏之、笠井潔、菊地浩吉、佐藤昇志、 松浦晃洋（札煶医大・医・病理）

主要組䄳道合遗伝子複合体（MHC）には多くの移植抗原 遗伝子に類似したクラス $b$ 遺伝子が存在するがその全容. 個々の機能については不明の点が多い。胸腺は丁リンパ 球産生の主たる甈器であり、胸腺外分化にも一定の影響を 与えているものと考えられる。我々はクラス lb 遗伝子の T 細胞分化に与える役割を明らかにすることを目的として、 まず最初にラット胸腺に発現するクラス b 遠伝子の解析 を行った。胸腺に多く発現する CDNA クローンを単離した。 RT1.N4 と命名された遺伝子はラットの他のクラス lb 遺 伝子とはかなり構造が異なるがマウス $\mathrm{T} 10 / \mathrm{T} 22$ と類似し ており、これらはラット・マウス分岐以前に生じた祖先遺 伝子由来で RT1.N ファミリーと総称しうる遺伝子群であ ることがわかった。RT1.Nはラットの体の大きさや精子形 成、発がん抵抗性を規定する成長・生殖寈伝子複合体 (growth and reproduction complex)にマップされる ことが報告されている。我々は、ゲノム遺伝子のクローニ ングを行い、6 個のゲノムクローンの解析から 2 個の類似 した遺伝子を同定した。RT1.Nファミリー迬伝子群の塩基 配列・オーガナイゼーションについて報告する。

\section{3-A5-192 クラス 1b の分子道伝学的解析}

II. CD 1 とV $\alpha 14$ 甶伝子多型についての解析: 松浦晃洋、 方波見重雄、杵渕幸、陳 宏之、笠井潔、菊地浩吉、佐 藤界志（札幌医大·医 ·病理）

$C D 1$ 抗原は疎水性の強いペプチドや糖脂質を $\mathrm{T}$ 細胞に提 示する抗原提示分子であり、 $V \alpha 14$ 陽性 NKT 細胞の正の 選択に関与していることが明らかにされている。我々はCD 1 抗原の多型性について系統的な解析を行うとともに、 $\vee \alpha$ 14 遺伝子の多型性の有無について検討した。CDiについ ては細胞外 $\alpha 1 、 \alpha 2$ ドメインが gl ycosyl phosphatidyl inositol (GPI)などの co-ligand の結合溝を形成するが、 この機能的に重要な部分における多型の有無について、サザ ンブロット法とP C R法により解析を加えた。後者について は、すでに報告してあるラットCD 1 の塩基配列をもとに、 同領域をコードするエクンン 2,3 をとりまくイントロン部 分にプライマーを作成し、1 2 系統のラットについてPCR 後、直接塩基配列の決定を行った。ラットは単一コピー遺伝 子であるため、他の逼伝子の配列か混在することなく、容易 にアリルを同定することができた。全体的に見ると極めて多 型性に乏しいか、119 番目のアミノ酸座位にアラニン（G C T ) あるいはバリン ( G T T ) に置換した allelic dimorphism が存在する。現在 $\vee \alpha 14$ についても同様な 解析を行っており、免度系のリガンドとレセプター遺伝子の 創成に何らかの相関が存在するか否かを検討中である。 
3-A5-193 クラスIbの分子遣伝学的解析

III. CD 1反応性 T 細胞レセプターVa 14 遗伝子の多様性と 均一性

陳 宏之、杵判 幸、笠井梁、松浦 晃洋

$\mathrm{CD} 1 反$ 応性 $\mathrm{T}$ 細胞のあるポビュレーションは均一な $\mathrm{T}$ 細胞 レセブターを有するV $\alpha 14$ 陽性 N K T 細胞である事がマウス で報告されている。我々はラットC D 1に反応する T細胞レセ フターの解析を目的として、まず最初にラットV $\alpha 14$ 遗伝子 の同定と発現バターンについて解析を行った。マウスV $\alpha 1$

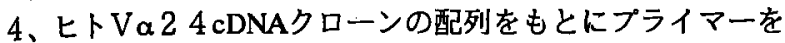
作成し、肝葴りンバ球cDNAを鋳型に增幅を行いプローブとし た。5'RACE法により、V領域を増幅したcDNAライブラリー

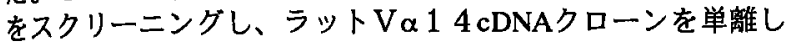
た。ラット配列をもとにVa 14 遗伝子の組織発現バターン、 $\mathrm{V}$ 一J 結合、N插入配列について検討した。胸腺ではV $\alpha 14$ に様々な J 遺伝子が結合した N 領域多様性のあるクローンが主 体であったが、䀒蔵ではJ $\alpha 281$ と良く似たJ頲伝子と結合 したN領域多様性がそしいものか高頻度にみられた。脾臟、骨 䯣についてもV ${ }^{2} 14$ 遺伝子発現について検索中である。以上 から、ラットにも均一な T C R $\alpha$ 鎖が存在することが明らかに なった。さらに增幅領域を延長し多数のcDNAクローンを詳細 に解析した所、いくつかの座位について塩基が変異した複数の V $\alpha 14$ 遺伝子が存在することが判明した。この結果は、より fidelityの高いボリメラーゼを有いたゲノム遺伝子の解析から確 認中である。多くのマウス系統には一個の遺伝子が存在すると いう以前の報告とは対照的であった。すなわち、ラット invariant T C R 鎖はV-J 結合領域は均一ではあるか、V領域 多様性が存在する。

\section{3-A5-194 ヒトNKT細胞の解析 : 大久保祐司、栜使河原計介、 丹羽大貫（京大・放生研七）}

T細胞マーカーであるCD3とNK細胞のマーカーであるNK1.1を もつNKT細胞が免疫系で重要な役割を持つことがマウスの実験 系を用いて明らかにされ，ヒトにおいてもNKT細胞の役割が注 目される.マウスNKT細胞マーカーのNK1.1に対するヒトにお けるhomologueであるNKRP-1A(CD161)は, CD3(-)， CD16(+)のNK細胞と一部のT細胞に認められるが，その中でど のようなsubpopulation に存在するかは不明な点が多い. 正常 ヒト末梢血の解析ではCD3(+)，CD161(+)の分画は少ないため 解析が困難であった．そこでK562細胞を標的としたMHC非拘 束性の細胞傷害活性を示す細胞分画をパーコールを用いた 7 段 階不連続比重遠心法で濃宿し，それを更にB7遺伝子を発現させ たK562細胞（K562/B7）で刺激し，IL-2存在下で培着した。 そ して，T細胞マーカーであるCD3(+)を持つ細胞でNKマーカー のCD161あるいはCD56を発現している細胞集団を検索したと ころ ((CD3 $(+), \mathrm{CD} 56(+), \mathrm{CD} 161(-)),((\mathrm{CD} 3(+), \mathrm{CD} 56(-)$, CD161(+)), ((CD3(+), CD56(+), CD161(+))に分類された. マ ウスではNKT細胞のTCR $\alpha$ 鎖はV $\alpha$ 14，CD161(+)のヒトNKT 細胞ではV $(x$ 24が使われていることが報告されている．そこで 抗V $\alpha 24$ 抗体を用いて解析したところこれらのヒトNKT細胞分 画ではCD161を発現していてもV $\alpha 24 の$ 発現は認められなかっ た. この結果はヒトNKT細胞はV $\alpha 24$ 以外のTCR $\alpha$ 鎖も用いて いる可能性を示唆しており，そのリガンドがどのようなもので あるかは興味の持たれるところであり現在解析中である.
3-A5-195

ヒトV $\alpha 24 \mathrm{NKT}$ 細胞は膫帯血に存在してい

る。：河野 鐵1、田中裕二郎1、佐藤 宏 1 、天野雅彦1、東 野和子1、伊藤俊広1、中山俊害1、長田久夫2、関谷宗英2、 谷口 克 1 (千葉大 - 院 - 免疫発生、2千葉大 - 医 - 産婦人 科)

【はじめに】第4のリンパ球と考えられているマウスV $\alpha$ 14NKT細胞の抗原受容体は、均一なV $\alpha 14$ 鎖とV $\beta 8.2$ 鎖か らなることが明らかにされている。ヒトにおいては、V $\mathrm{\alpha} 14$ 受容体のホモログとしてV $\alpha 24$ 受容体が知られている。臍带 血は多能性血液幹細胞を含むことから、近年、骨髄移植医療 において注目されているが、臍帯血中にV $\alpha 24 \mathrm{NKT}$ 細胞が存 在しているのか、またそれらがどのようなV $\beta$ を使用いるの か不明である。今回我々は、ヒ卜臍帯血をスクリーニングし えたので報告する。

【材料と方法】インフォームドコンセントの上、了解の得ら れた症例について、4〜60 $\mathrm{ml}$ の臍带血を採取した。Ficollを もちいて単核球を単離したのち、1X106個の細胞を3重染色 し、これらをFACS解析した。

【結果と考察】 V $\alpha 24 \mathrm{NKT}$ 細胞は全症例において存在してお

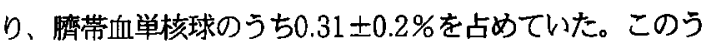

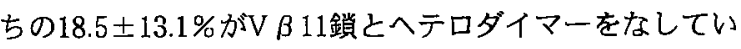
た。マウスV $\alpha 14 \mathrm{NKT}$ 細胞のヒトホモログが $\alpha 24^{+} \mathrm{V} \beta 11$ 十細胞なのかV $\alpha 24^{+} \mathrm{V} \beta 11^{-}$細胞であるのかについて現在検 討している。

3-A5-196 Activation of human V $\alpha 24 \mathrm{NKT}$ cells by $\alpha$-glycosylceramide in a CD1d-restricted and Vo24TCR-mediated manner: Mie NIEDA', Andrew $\mathrm{NICOL}^{2}$, Tsuyoshi TAKAHASHI ${ }^{3}$. Akiko KIKUCHI, Yasuhiko KOEZUKA ${ }^{4}$, Hiroshi FURUKAWA ${ }^{3}$, Toshio YABE ${ }^{1}$, Yoshihide ISHIKAWA', Kenji TADOKORO' ${ }^{1}$ and Takeo JUJI ${ }^{1}$ ('Department of Research, The Japanese Red Central Blood Center, ${ }^{2}$ Department of Hematology, Royal Brisbane Hospital, Australia, ${ }^{3}$ Faculty of Medicine, University of Tokyo, ${ }^{4}$ Pharmaceutical Research Laboratory, Kirin Brewery)

V $\alpha 14 \mathrm{NK}$ (natural killer) $\mathrm{T}$ cells play an important role in controlling tumors or in preventing autoimmunity in murine system. Va24NKT cells, the human counterpart of V $\alpha 14$ NKT cells, contribute to control the progress of autoimmune diseases in humans. These findings show the possibility that ligand(s) for these NKT cells can control abovementioned pathological conditions. Specific glycolipids such as $\alpha$ galactosylceramide and $\alpha$-glucosylceramide have been identified as ligand(s) recognized by murine V $\alpha 14 \mathrm{NKT}$ cells in a CDld restricted manner, but it remains unclear whether these glycolipids are ligand(s) for V $\alpha 24 \mathrm{NKT}$ cells in humans. To determine whether $\alpha$ glycosylceramide is presented by CD1d molecules in humans, we established a V $\alpha 24 \mathrm{NKT}$ cell line specific for $\alpha$-glycosylceramide using dendritic cell like cells from normal peripheral blood mononuclear cells in autologous mixed leukocyte reaction system, and characterized the V $\alpha 24$ NKT cell line. The V $\alpha 24$ NKT cells were CD4CD8-V $\alpha 24+V \beta 11+N K R P 1 A+$ and specifically proliferated in response to $\alpha$-glycosylceramide in CD1d-restricted and V $\alpha 24 T C R$ mediated manner. The phenotypic and functional similarities between murine V $\alpha 14$ NKT cells and human V $\alpha 24$ NKT cells suggest that V $\alpha 24 \mathrm{NKT}$ cells may play an important role in controlling tumors or in preventing autoimmunity as observed with $\mathrm{V} \alpha 14 \mathrm{NKT}$ cells. 
3-A5-197 未梢血中 $\mathrm{CD} 4^{-} \mathrm{CD} 8^{-} \mathrm{TCR} \vee \propto 24^{+} \mathrm{T}$ 細胞の表面形 質：森井武志 ${ }^{1}=2$ 、䐝田美江 ${ }^{1}$ 、高橋強志 ${ }^{1}$ ， 3 、石川善英 ${ }^{1}$ 、 十字猛夫 ( $^{1}$ 日赤・中央血液七ンタ一、奈良県医大・2 内、 3果大・医・血液内科)

【目的】ヒト $\mathrm{CD}^{-} \mathrm{CD}^{-} \mathrm{TCR} \vee \alpha 24^{+} \Upsilon$ 細胞はマウスの $\mathrm{V}$ a $14^{+} \mathrm{NKT}$ 細胞に相当すると考えられるが、健常人末梢血中 にはごく少数しか存在しないため、これまでその表面形質の 報告はいずれも培養增殖した細胞のものであった。今回我々 は培盖刺激を受けていない $\mathrm{CD}^{-}{ }^{-} \mathrm{CD} 8^{-} \mathrm{TCR} V \alpha 24^{+} \mathrm{T}$ 細胞の 表面形質を検討した。

【方法】Cy5 標識 CD4、Cy5 標識 CD8、FITC 標識あるいは PE 標識 TCR V a 24 抗体と FITC 標識あるいはPE 標識各種 抗体を用いフローサイトメトリー法にて 3-color analysis を健 常人 5 例で行った。 $\mathrm{CD}^{-} \mathrm{CD}^{-} \mathrm{TCR} \vee \alpha 24^{+}$のリンバ球集団 にゲートを設定し、50万個から 100 万個の細胞を測定するこ とによりその表面形質を解析した。また健常人 50 例で末梢血 リンパ球中の㓶合を測定した。

【結果】 $\mathrm{CD}^{-} \mathrm{CD}^{-} \mathrm{TCR} \vee{ }_{2} 24^{+}$細胞はすべて $\mathrm{CD161}{ }^{+}$

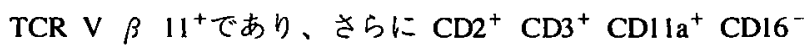
$\mathrm{CD} 18^{+} \mathrm{CD}^{-} 5^{-} \mathrm{CD} 28^{+} \mathrm{CD}^{-} 4^{-} \mathrm{CD} 54^{-} \mathrm{CD}^{ \pm} 6^{ \pm} \mathrm{CD}^{-} 7^{-} \mathrm{CD} 69^{ \pm}$ $\mathrm{CD}_{4}{ }^{-} \mathrm{CD} 95^{+} \mathrm{CD} 122^{+} \mathrm{CD}_{52} 2^{-} \mathrm{CD} 154^{-} \mathrm{CD} 158 \mathrm{a}^{-} \mathrm{CD} 158 \mathrm{~b}^{-}$ HLA-DR- NKB1- であった。また末梢血りンパ球中に占める 割合の mean $\pm S D$ は $0.029 \pm 0.035 \%$ 、中央值は $0.016 \%$ であっ た。

\section{3-A5-198}

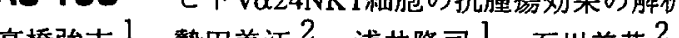

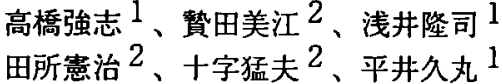

（1 東大・医・血液内科、2 日赤中央血液センター)

ヒトV $\alpha 24 \mathrm{NKT}$ 細胞は、NKレセプターNKRP1とT細胞レセ プターを併せ持つユニークなリンパ球である。T細胞レセプ ターはV 24 が使用され、クラス様分子CDldに拘束されマ ウスのVo14NKT細胞に相当すると思われる。また刺激によ り IL-4、IFN- $\gamma$ とっったイトカインを分泌し免疫応答にお いて重要な役割を担っていることが予想されている。今回 我々は、ヒトV $\alpha 24 N K T$ 細胞の抗腫湯効果に関して検討を行 つた。健常人末梢血より得た樹状細胞に $\alpha$-galactosylceramide を添加しリンバ球と混合培盖することによりヒトV $2424 \mathrm{NKT}$ 細胞を誘導することができた。得られたV $\alpha 24 \mathrm{NKT}$ 細胞は抗 V $\alpha 24$ 抗体で回収したが、TCR VßはほとんどVß11が使われ ていた。CD4-CD8-及びCD4+CD8-の亜集団に分けられたが、 いずれもCD1dによって抗原提示を受け增殖した。この $2 つ$ の亜集団はU937細胞を始めとするある種の腫瘍細胞株に対 し同様の細胞障害活性を示し、その活性はIL-12によって增 強された。また、NK感受性細胞であるK562細胞に対する細 胞障害活性は弱くNK細胞とは異なった標的細胞認識機粠が 存在することが示唆された。
3-A6-199 抗CCR5抗体(2D7)に結合するペプチドモチーフの 解析：米田明広、鳥越直彦、都甲直美、伊東祐二、杉村和久 (鹿大·I·分子生物)

【目的】

マクロファージ親和型(Mトロピック)HIV-1の細胞への感染は、 まずウィルス膜上のgp120が、細胞上に発現しているCD4分 子と結合し、その際に立体構造が変化したgp120が、CCR5分 子と結合することで成立する。本研究では、gp120/CD4 と CCR5との結合を阻害し、MトロピックHIV-1の細胞への感染 を阻害することを目的として、ファージディスプレイライフ ラリーから抗CCR5抗体(2D7)に特異的に結合するファージを 単離し、それぞれのファージに含まれる15残基のペプチドモ チーフの解析を試みた。

【方法と結果】

CCR5は細胞膜を7回貫通しているレセプターであるが、2D7 はCCR5の細胞外第二ループ領域を認識し、CCR5のリガンド である $\beta$-ケモカイン(MP-1 $\alpha \cdot$ MIP-1 $\beta$ - RANTES)の結合、ま たMトロピックHIV-1の感染も阻害する。この抗体を鋳型と し、以前に示したバイオパンニング法を用いてファージを単 離した。ELISAによるスクリーニングの結果、9クローンの ファージが2D7との結合活性を示し、さらに、それらのファ 一ジに含まれる15残基のアミノ酸配列をシークエンスした結 果、3種類のモチーフに分類することができた。また、これ らのモチーフは2D7との特異的結合活性を示したことから、 CCR5㥞モチーフとして機能している可能性が示唆された。

本演題では、これらのCCR5様モチーフのMトロピック HIV-1 感染阻害活性、 $\beta$-ケモカインとの結合活性、また、合 成ペブチドにおける活性について発表する予定である。

非会員共同研究者：

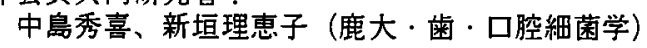

3-A6-200 T-tropic HIV-1のgp120 V3領域に対応したループ化 ペプチドのCXCR4結合能とHIV-1感染抑制活性 : 阪井田仁士1

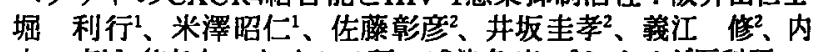
山 卓 ${ }^{13}$ ('京大・ウイルス研・感染免疫、 ${ }^{2}$ シオノギ医科研、

京大・医・血渡病態)

【目的】咋年度の本学会において、われわれは、独自に澍立 した抗CXCR4抗体とT-tropic HIV-1 gp1200V3領域に対応した ループ化ペプチドを用いて、V3領域とCXCR4の直接的な結合 を示唆するデータを提示した。今回、新たに合成した直銷型 ペプチドおよびM-tropicなウイルスのV3ループペブチドとの比 較によって、その結合の特異性を確認するとともに、HIV-1の 感染に対するこれらのペプチドの影稫およびCD4存在下および 非存在下における gp120とCXCR4の結合についても検討した。 【方法と結果】T-tropicなHIV-IIBのV3領域に対応したループ 化べブチドV3-BH10と直鎖型ペプチドCTR36、HIV-1 ELIのそ れに対応したV3-ELI、そしてM-tropicなHIV-1ADAとdual tropic な89.6のV3領域に対応したルーブ化べブチドV3-ADAとV389.6の計 5 個のペプチドを合成した。CD4隆性のヒトB細胞株 JYに上記のペプチドを反応させた後、抗CXCR4抗体IVR7で架 色し、FACScanにて解析した結果、V3-BH10、V3-ELI、V389.6はIVR7 とCXR4の結合を阴害したが、CTR36とV3-ADAは 影響を与えなかった。ヒトT細胞株SupT1およびJYにHIV-1 SF2 のgp1 20を反応させて同様の実験を行ったところ、両者の級胞 でgp120によるIVRとCXCR4の結合阻害が検出された。さらに。 MT-4細胞へのHIV-1感染のMTTアッセイと逆轱写醉素澌定に よる定量化㬰験において、上記前者の3 個のペプチドはTtropic HIV-1の感染を抑制したが、後者の2 個のペプチドは㱠 ど抑制作用を示さなかった。【考察】以上の結果から、Ttropic HIV-1のgp120のV3ループ領域が他のgp120領域やCD4K 非依存性に直接CXCR4に結合しうることが示された。これら のペプチドは抗HIV-1陚楽としてHIV-1の細胞侵入機橉の解析 に有用であると思われる。 